\title{
SHARE OF ANTHROPOPHYTES IN THE CROP SEQUENCE: WINTER WHEAT - MAIZE - SPRING WHEAT DEPENDING ON TILLAGE SYSTEM
}

\author{
${ }^{1}$ Tomasz R. Sekutowski, ${ }^{2}$ Janusz Smagacz \\ Institute of Soil Science and Plant Cultivation, National Research Institute \\ ${ }^{1}$ Department of Weed Science and Tillage Systems, Orzechowa 61, 50-540 Wroclaw, Poland \\ ${ }^{2}$ Department of Systems and Economics of Crop Production, Czartoryskich 8, 24-100 Pulawy, Poland \\ e-mail: t.sekutowski@iung.wroclaw.pl
}

Received: 30.03.2013

\begin{abstract}
An experiment, conducted over the period 2008-2010, evaluated the effect of tillage system on the occurrence and species composition of anthropophytes in winter wheat, maize and spring wheat. Regardless of crop plant and tillage system, anthropophytes (73.9\%), represented by archaeophytes and kenophytes, were the main component of the flora in the crops studied, whereas apophytes accounted for the remaining $26.1 \%$. Most archaeophytes (13 species) were found in the spring wheat crop under no-tillage, while their lowest number (6 species) occurred in the spring wheat crop under conventional tillage. The only kenophyte, Conyza canadensis, was found to occur in the spring wheat and maize crops in the no-tillage system. The following taxa were dominant species among archeophytes: Geranium pusillum, Anthemis arvensis, and Viola arvensis (regardless of tillage system and crop plant), Anthemis arvensis (in spring wheat - conventional tillage), Echinochloa crus-galli and Setaria glauca (in maize - reduced tillage and no-tillage), Chenopodium album (in maize - no-tillage) as well as Apera spica-venti, Anthemis arvensis and Papaver rhoeas (in winter wheat - no-tillage).
\end{abstract}

Key words: anthropophytes, tillage system, winter wheat, maize, spring wheat

\section{INTRODUCTION}

Plant communities accompanying field crops are determined by habitat conditions and agronomic practices used (e.g. type of previous crop, tillage system, fertilization, or crop protection treatments, etc.) [1-4]. Plant cover transformations resulting from the effects of anthropogenic factors are termed synanthropization [5]. As a result of human (farming) activity, a decrease in the number of stenotopic species in favor of apophytes and anthropophytes can be observed [3,6-8].

Reduced tillage is one of the factors that shape agrophytocenoses, since this tillage system contributes to the creation of different growth and development conditions for the crop plant and weeds. The use of reduced tillage practices in crop rotations also creates conditions for compensation or temporary disappearance of some weed species [9-11].

The aim of this study was to determine the effect of tillage system on the occurrence and species composition of anthropophytes in the crop sequence: winter wheat - maize - spring wheat.

\section{MATERIALS AND METHODS}

Crop growing experiments with winter wheat, maize and spring wheat were conducted over the period 2008-2010 in production fields of the Jelcz-Laskowice Experimental Station of the Institute of Soil Science and Plant Cultivation (IUNG-PIB). Experimental fields (for each crop plant separate) were divided into three parts that differed in tillage system: conventional tillage, reduced tillage, and no-tillage (direct drilling). More important elements associated with the tillage systems used during the 3-year study period are shown in Table 1.

The research material consisted of the results of observations of the state and level of weed infestation of the respective crops depending on tillage system. The analysis of weed infestation, that is, the species composition of weeds and their number per unit area, was performed using the quadrat sampling method. Quadrat sampling was carried out twice during the growth period: 2 weeks before herbicide application 
and 4 weeks before crop harvest (separately for each tillage system) [12].

The results obtained from the observations allowed us to make a list of species found in the experiments; these species were broken down into apophytes and anthropophytes, among which archeophytes [8,13] and kenophytes $[8,14]$ were distinguished. Species nomenclature used in this paper follows $\mathrm{Mirek}$ et al. [15], whereas the assignment of species to historical-geographical groups was determined according to Sikorski et al. [3], Latowski et al. [8], and $\mathrm{J}$ a c k ow i a k [16]. Furthermore, species found in the experiments were divided into annual and perennial ones $[17,18]$.

Table 1

Tillage system

\begin{tabular}{cc}
\hline Tillage system & Tillage operations \\
\hline Conventional tillage & $\begin{array}{c}\text { grubber at } 15 \mathrm{~cm}+\text { string roller } \\
\text { ploughing to a depth of } 25 \mathrm{~cm} \\
\text { tillage unit (cultivator }+ \text { string roller) }\end{array}$ \\
\hline Reduced tillage & grubber at $15 \mathrm{~cm}$ \\
No-tillage & tillage aggregate (cultivator + string roller) \\
\hline herbicide Roundup 360 SL at a rate of 4.01 per ha \\
direct drilling
\end{tabular}

\section{RESULTS}

Regardless of tillage system, 11 weed species were found to occur in the winter wheat crop in 2008. Among them, 5 native species (apophytes) were distinguished, which accounted for $45.5 \%$ of the total number of taxa. The other 6 species belonged to alien taxa (anthropophytes) which accounted for the remaining $54.5 \%$. Only archaeophytes were found to occur in the group of anthropophytes (Table 2).

The highest incidence of apophytes in the winter wheat crop was found under no-tillage, it was lower under reduced tillage, while they showed the lowest cover in conventional tillage. Among apophytes, annual species (therophytes) were predominant, whereas from perennial species only 2 geophytes occurred, out of which only Elymus repens was found in the no-tillage system. Anthropophytes also had the largest numbers under no-till conditions, followed by reduced tillage, and the lowest numbers were observed in conventional tillage. In this case, archaeophytes, among which only therophytes were found to occur, were the group of anthropophytes that determined the level of weed infestation of the winter wheat crop depending on tillage system. 4 therophytes: Apera spica-venti, Geranium pusillum, Anthemis arvensis and Viola arvensis, determined the level of weed infestation in the winter wheat crop (in particular under no-tillage and reduced tillage conditions) (Table 2).

15 weed species were found to occur in the maize crop in 2009. 6 apophytes were distinguished among them and they accounted for $40.0 \%$ of the total number of all taxa. The remaining 9 species belonged to anthropophytes and constituted $60.0 \%$ of the total flora.
Archaeophytes (8 species) were the dominant group of anthropophytes, whereas kenophytes were only represented by one species - Conyza canadensis (Table 2).

Most native species (apophytes) were found under no-till, followed by reduced and conventional tillage. Perennial species predominated among apophytes - 3 geophytes: Elymus repens (observed only under no-tillage), Cirsium arvense and Equisetum arvense as well as one chamaephyte: Artemisia vulgaris. The other native species, Chenopodium album and Setaria glauca, belonged to annual ones (therophytes). Among anthropophytes, the dominant group was made up of alien species (archaeophytes), among which only therophytes were found to occur. The following monocotyledons: Echinochloa crus-galli and Setaria glauca, were dominant taxa in this group under no-tillage and reduced tillage. On the other hand, only one dicotyledonous species, Geranium pusillum, was found under conventional and reduced tillage. Moreover, the only kenophyte found - Conyza canadensis, which occurred only under no-till, did not play a major role in weed infestation of the maize crop (Table 2).

In 2010 the highest number of weed species was found in the spring wheat crop. Regardless of tillage system, 22 taxa occurred in it, out of which 8 belonged to apophytes (36.4\% of the total number of species) and 14 to anthropophytes (63.6\% of the total number). Among anthropophytes, archaeophytes (13 species) predominated over kenophytes (1 species) (Table 2).

No-tillage was characterized by the highest number of apophytes (8 species). Perennial taxa - Elymus repens (geophyte), Equisetum arvense (geophyte), and Artemisia vulgaris (chamaephyte), were found only in this tillage system. A native geophyte - Cirsium 
arvense, occurred as the only one in all the three tillage systems. Under reduced and conventional tillage, 4 native species were found to occur; they belonged to therophytes (Chenopodium album, Stellaria media, and Veronica hederifolia) and geophytes (Cirsium arvense). Most taxa infesting the spring wheat crop were anthropophytes, among them annual archaeophytes. The following species were predominant under no-till: Echinochloa crus-galli and Setaria glauca as well as 4 dicotyledonous species: Geranium pusillum, Anthe- mis arvensis, Lamium purpureum, and Viola arvensis. 2 therophytes, Lamium purpureum and Myosotis arvensis, and one kenophyte - Conyza Canadensis, were found to occur only in the no-tillage system. Nevertheless, apart from Lamium purpureum, they were of marginal importance for weed infestation of the spring wheat crop. Under reduced and conventional tillage, only 4 dicotyledonous therophytes occurred, i.e. Anthemis arvensis, Geranium pusillum, Papaver rhoeas, and Viola arvensis (Table 2).

Table 2

List of anthropophytes and apophytes in particular crop rotations and their numbers (plants $\times \mathrm{m}^{-2}$ ) depending on tillage system

\begin{tabular}{|c|c|c|c|c|c|c|c|c|c|c|c|}
\hline \multirow{5}{*}{ Species name } & \multirow{5}{*}{$\begin{array}{c}\text { Geographical } \\
\text {-historical } \\
\text { groups }\end{array}$} & \multirow{5}{*}{ Persistence } & \multicolumn{3}{|c|}{ Conventional tillage } & \multirow{2}{*}{\multicolumn{3}{|c|}{$\begin{array}{l}\text { Reduced tillage } \\
\text { Year of study }\end{array}$}} & \multicolumn{3}{|c|}{ No-tillage } \\
\hline & & & & & & & & & & & \\
\hline & & & 2008 & 2009 & 2010 & 2008 & 2009 & 2010 & 2008 & 2009 & 2010 \\
\hline & & & \multicolumn{9}{|c|}{ Crop plant } \\
\hline & & & $\begin{array}{l}\text { Winter } \\
\text { wheat }\end{array}$ & Maize & $\begin{array}{l}\text { Spring } \\
\text { wheat }\end{array}$ & $\begin{array}{l}\text { Winter } \\
\text { wheat }\end{array}$ & Maize & $\begin{array}{l}\text { Spring } \\
\text { wheat }\end{array}$ & $\begin{array}{l}\text { Winter } \\
\text { wheat }\end{array}$ & Maize & $\begin{array}{l}\text { Spring } \\
\text { wheat }\end{array}$ \\
\hline I & II & III & IV & $\mathrm{V}$ & VI & VII & VIII & IX & $\mathrm{X}$ & XI & XII \\
\hline $\begin{array}{l}\text { Agropyron repens (L.) } \\
\text { P. Beauv. }\end{array}$ & ap;g & $\mathrm{p}$ & - & - & - & - & - & - & 1.5 & 0.5 & 0.1 \\
\hline Anthemis arvensis L. & ar; $\mathrm{t}$ & $\mathrm{a}$ & 2.5 & 1.0 & 5.7 & 3.5 & 1.3 & 2.5 & 8.0 & 1.0 & 2.5 \\
\hline $\begin{array}{l}\text { Apera spica-venti (L.) } \\
\text { P. Beauv. }\end{array}$ & ar; $\mathrm{t}$ & $\mathrm{a}$ & 2.5 & - & 1.0 & 4.5 & - & 1.5 & 11.0 & - & 0.7 \\
\hline Artemisia vulgaris L. & ap; ch & $\mathrm{p}$ & - & 0.3 & - & - & 0.5 & - & - & 1.6 & 0.5 \\
\hline $\begin{array}{l}\text { Capsella bursa-pastoris } \\
\text { (L.) Medik. }\end{array}$ & ar; t & $\mathrm{a}$ & - & - & 0.7 & - & - & 1.0 & - & - & 1.2 \\
\hline Centaurea cyanus L. & ar; t & $\mathrm{a}$ & 1.5 & - & 1.0 & 2.0 & - & 1.2 & 6.5 & - & 1.5 \\
\hline $\begin{array}{l}\text { Cirsium arvense (L.) } \\
\text { Scop. }\end{array}$ & ap; g & $\mathrm{p}$ & 0.2 & 0.7 & 0.2 & 0.3 & 0.8 & 0.5 & 1.3 & 1.5 & 0.7 \\
\hline Chenopodium album $\mathrm{L}$. & ap; t & $\mathrm{a}$ & 0.5 & 1.8 & 0.5 & 0.5 & 2.5 & 0.7 & 1.0 & 4.3 & 1.5 \\
\hline $\begin{array}{l}\text { Conyza canadensis (L.) } \\
\text { Cronquist }\end{array}$ & $\mathrm{kn} ; \mathrm{t}$ & $\mathrm{a}$ & - & - & - & - & - & - & - & 1.2 & 0.1 \\
\hline $\begin{array}{l}\text { Descurainia sophia } \\
\text { (L.) Webb ex Prantl }\end{array}$ & ar; $\mathrm{t}$ & $\mathrm{a}$ & - & 0.6 & - & - & 0.7 & 1.0 & - & 0.9 & 0.8 \\
\hline $\begin{array}{l}\text { Echinochloa crus-galli } \\
\text { (L.) P. Beauv. }\end{array}$ & ar; t & a & - & 4.8 & 0.2 & - & 5.0 & 0.5 & - & 8.5 & 3.0 \\
\hline Equisetum arvense $\mathrm{L}$. & ap; g & $\mathrm{p}$ & - & 0.2 & - & - & 0.3 & - & - & 0.7 & 0.5 \\
\hline $\begin{array}{l}\text { Fallopia convolvulus } \\
\text { (L.) A. Löve }\end{array}$ & ar; t & $\mathrm{a}$ & - & 1.3 & - & - & 3.5 & - & - & 2.5 & - \\
\hline Galium aparine $\mathrm{L}$. & ap; t & $\mathrm{a}$ & 0.5 & - & - & 0.8 & - & - & 1.5 & - & 0.5 \\
\hline $\begin{array}{l}\text { Geranium pusillum } \\
\text { Burm. F. ex L. }\end{array}$ & ar; $\mathrm{t}$ & $\mathrm{a}$ & 7.0 & 6.0 & 1.3 & 11.5 & 7.8 & 4.0 & 10.0 & 2.8 & 7.0 \\
\hline $\begin{array}{l}\text { Myosotis arvensis (L.) } \\
\text { Hill. }\end{array}$ & ar; t & $\mathrm{a}$ & - & - & - & - & - & - & - & - & 1.7 \\
\hline Papaver rhoeas L. & ar; t & $\mathrm{a}$ & 2.0 & - & 4.5 & 2.8 & - & 3.0 & 5.0 & - & 1.2 \\
\hline $\begin{array}{l}\text { Setaria glauca (L.) } \\
\text { P. Beauv. }\end{array}$ & ar; t & $\mathrm{a}$ & - & 3.5 & 0.2 & - & 6.5 & 0.5 & - & 15.5 & 4.2 \\
\hline Stellaria media (L.) Vill. & ap; t & a & - & 1.0 & 0.7 & - & 1.0 & 1.7 & - & 0.7 & 1.7 \\
\hline Thlaspi arvense L. & ar; t & $\mathrm{a}$ & - & 1.0 & 1.0 & - & 1.0 & 1.0 & - & 0.7 & 1.2 \\
\hline Veronica hederifolia L. & ap; t & $\mathrm{a}$ & 1.3 & - & 1.5 & 1.3 & - & 2.0 & 1.8 & - & 1.2 \\
\hline Viola arvensis Murray & ar; t & $\mathrm{a}$ & 3.5 & 1.8 & 3.3 & 4.5 & 1.2 & 4.7 & 7.0 & 4.8 & 2.0 \\
\hline
\end{tabular}

Explanations: ap - apophyte, ar - archaeophyte, kn - kenophyte, ch - chamaephyte, g-geophyte, t - therophyte, a - annual, p - perennial 


\section{DISCUSSION}

In the opinion of K o r $n$ as s [19], the human impact on flora results in changes in its composition and as a result of this impact some species spread, while some other ones disappear. Depending on these processes, floristic diversity can increase or decrease.

The data on weed infestation of agrophytocenoses of cereal plants, in dependence of agronomic practices used, are included in numerous papers. In the opinion of S z y m a n ki e w i c z et al. [20] as well as Ję druszczak and Antoszek [21], reduced tillage practices and the use of crop rotation or its abandonment cause not only quantitative changes, but also qualitative changes in weed communities. This is manifested in the fact that communities in which there is relatively high biodiversity are replaced by simplified weed communities, mostly composed of several dominant species, e.g. Apera spica-venti, Papaver rhoeas, Centaurea cyanus, or Viola arvensis. According to Stupnicka-Rodzynkiewicz et al. [1], the harmfulness of weed communities composed of several species is often greater than that of a community made up of a dozen or more taxa. In this case, the harmfulness of weeds results not from the number of species, but from their total numbers and the total weight of weeds. This thesis is confirmed by the results of the present study conducted on the first component of the crop rotation, that is, spring wheat.

W oźniak [22] also showed that the dry weight of weeds in a spring wheat crop significantly increased under ploughless tillage conditions compared to conventional tillage. Under plough tillage, spring wheat was most frequently colonized by native therophytes (apophytes), i.e. Avena fatua, Stellaria media, Chenopodium album, and Galium aparine, as well as by an annual archaeophyte Consolida regalis and a kenophyte Amaranthus retroflexus. Under ploughless tillage, on the other hand, apart from 4 annual apophytes, 2 annual archaeophytes, i.e. Fallopia convolvulus and Papaver rhoeas, also occurred as dominants.

This thesis is confirmed by the results of the present study in which 8 apophytes were found to occur in the spring wheat crop under no-tillage, among them 2 perennial geophytes, i.e. Elymus repens and Equisetum arvense, as well as one chamaephyte - Artemisia vulgaris. But under reduced and conventional tillage, only 4 native species were found to be present; therophytes predominated among them, i.e. Chenopodium album, Stellaria media and Veronica hederifolia, as well as one geophyte - Cirsium arvense.

According to S o w i ń s k i [23], annual species, an apophyte Chenopodium album as well as kenophytes Amaranthus retroflexus and Galinsoga parviflora, contribute to typical weed infestation of maize crops. When determining the effect of previous crop on the species composition of weeds in maize grown after cereals, P u d e $1 \mathrm{k}$ o et al. [24] included annual archeophytes, i.e. Stellaria media, Veronica arvensis, Capsella bursa-pastoris, and Setaria viridis, in dominant taxa. The above data are partially consistent with the results of the present study. The occurrence of apophytes, archaeophytes or kenophytes can also be modified by tillage systems, aside from the crop plant itself. An example is no-till under which a perennial apophyte, Artemisia vulgari, was found to occur in great numbers. This thesis is confirmed by the study of G o ł e b i ow s ka and K a u s [25] who also observed increased numbers of this chamaephyte in crops sown using direct drilling. The situation is similar in the case of kenophytes such as Conyza canadensis and Solidago canadensis, which are observed more and more frequently in maize, particularly under direct drilling. Jezierska-Domaradzka and Domaradzki [26] observed that Solidago canadensis encroached into a maize field that was in close vicinity to an abandoned field. In the opinion of $\mathrm{J}$ ę $\mathrm{d} \mathrm{r} \mathrm{u} \mathrm{s} \mathrm{z} \mathrm{c} \mathrm{z} \mathrm{a} \mathrm{k}$ and A ntos zek [21], species attached to conditions created as a result of human activity (e.g. by using reduced tillage practices) are few and can appear a bit more distinctly in small amounts only in single years of research.

\section{CONCLUSIONS}

1. Regardless of crop plant and tillage system used, antropophytes $(73.9 \%)$, represented by archaeophytes and kenophytes, were the main component infesting the crop plants studied. Apophytes made up the remaining $26.1 \%$ of the weed community.

2. Tillage system was a factor modifying the occurrence of archaeophytes and kenophytes. Most archaeophytes (13 species) were found in the spring wheat crop under no-tillage, while their least amount (6 species) in the winter wheat crop under conventional tillage. The kenophyte Conyza canadensis occurred only under no-till in the spring wheat and maize crops.

3. Only 5 species (out of 23 found) were present in each type of crop, including 2 apophytes (Chenopodium album and Cirsium arvense) as well as 3 archaeophytes (Geranium pusillum, Anthemis arvensis and Viola arvensis).

4. Among archaeophytes, Geranium pusillum, Anthemis arvensis and Viola arvensis were dominant species in the crops studied.

\section{Acknowledgments}

The work has been prepared as a part of 2.6 Long-term Program in the Institute of Soil Science and 
Plant Cultivation - State Research Institute (funded by the Polish Ministry of Agriculture and Rural Development).

\section{Authors' contributions}

The following declarations about authors' contributions to the research have been made: design of the experiments: TRS, JS; performance of the experiments: TRS; analysis of the experimental data: TRS, JS; writing of the paper: TRS.

\section{REFERENCES}

1. Stupnicka-Rodzynkiewicz E, Stępnik K, Lepiarczyk A. Wpływ zmianowania, sposobu uprawy roli i herbicydów na bioróżnorodność zbiorowisk chwastów [Effect of the crop rotation, tillage method and herbicides on the biodiversity of weed communities]. Acta Sci Pol Agric. 2004; 3(2): 235-245.

2. Szeleźniak E, Grabiński J, Nieróbca P. Wpływ intensywności technologii produkcji wybranych gatunków zbóż na ich zachwaszczenie [Weed infestation of three grain species cultivated under cereal crop rotation and three technologies varying in production intensity]. Acta Sci Pol Agric. 2007; 6(4): 83-90.

3. Sikorski R, Krechowski J, Piórek K. Udział antropofitów w uprawach kukurydzy (Zea mays L.) na terenie Wysoczyzny Siedleckiej [Share of anthropophytes in the maize (Zea mays L.) cultivations of the Siedlecka Upland]. Fragm Agron. 2010; 27(2): 111-117.

4. Woźniak A, Haliniarz M. The after-effect of long-term reduced tillage systems on the biodiversity of weeds in spring crops. Acta Agrobot. 2012; 65(1): 141-148. http:// dx.doi.org/10.5586/aa.2012.052

5. Korna ś J . Analiza flor synantropijnych. Wiad Bot. 1977; 21(2): 85-91.

6. Ciaciura M, Więcław H, Stępień E, Myśliwy M. Główne kierunki antropogenicznych przemian flory roślin naczyniowych parków krajobrazowych Pomorza Zachodniego [Main directions of anthropogenic changes of the vascular plants' flora of landscape parks in Western Pomerania]. Zesz Nauk U Sz Acta Biol. 2007; 503(14): 63-69.

7. Kapeluszny J, Haliniarz M. Niektóre gatunki ruderalne zadomowione w uprawach na terenie województwa lubelskiego [Some ruderal weeds settled in the crops in the Lublin region]. Fragm Agron. 2010; 27(2): 70-78.

8. Latowski K, Chmiel J, Jackowiak B, Żukowski W. Udział antropofitów we florze segetalnej Wielkopolski [Participation of anthropophytes in the segetal flora of Wielkopolska]. Fragm Agron. 2010; 27(3): 103-111.

9. Majchrzak L, Skrzypczak G, Pudełko J. Wpływ systemów uprawy roli na skuteczność chwastobójczą herbicydów stosowanych w kukurydzy [The effect of soil tillage systems on the effectiveness of herbicides in maize]. Prog Plant Prot Post Ochr Roślin. 2003; 43(2): 791-794.
10. Szulc P, Menzel L, Dubas A. Wpływ uproszczeń w uprawie roli na stan zachwaszczenia kukurydzy uprawianej w monokulturze [Impact of tillage minimization on weed infestation in maize grown in monoculture]. Prog Plant Prot Post Ochr Roślin. 2005; 45(2): 1137-1140.

11. S ekutowski T, Domaradzki K. Bioróżnorodność gatunkowa chwastów w monokulturze pszenicy ozimej $\mathrm{w}$ warunkach stosowania uproszczeń w uprawie roli [Biodiversity of weed species in winter wheat monoculture caused by reduced of tillage]. Fragm Agron. 2009; 26(4): 160-169.

12. Domaradzki K, Badowski M, Filipiak K, Franek M, Gołębiowska H, Kieloch R, et al. Metodyka doświadczeń biologicznej oceny herbicydów, bioregulatorów i adiuwantów. Cz. 1. Doświadczenia polowe. Puławy: Wyd IUNG; 2001.

13. Zając E, Zając A. Lista archeofitów występujących w Polsce. Zesz Nauk UJ Pr Bot. 1975; 3: 7-16.

14. Tokarska-Guzik B. The establishment and spread of alien plant species (kenophytes) in the flora of Poland. Pr Nauk UŚ. 2005; ??(??): ??.

15. Mirek Z, Piękoś-Mirkowa H, Zając A, $\mathrm{Zaj}$ ąc M. Flowering plants and pteridophytes of Poland. A checklist. Krytyczna lista roślin naczyniowych Polski. Cracow: W. Szafer Institute of Botany, Polish Academy of Sciences; 2002.

16. Jackowiak B. Atlas rozmieszczenia roślin naczyniowych w Poznaniu [Atlas of distribution of vascular plants in Poznan]. Pr Zakł Taks Rośl UAM. 1993; 2(??): ??.

17. Szweykowska A, Szweykowski J. Słownik botaniczny. Warsaw: Wyd PW Wiedza Powszechna; 2003.

18. Sudnik-Wój cikowska B. Flora Polski. Rośliny synantropijne. Warsaw: Multico Oficyna Wydawnicza; 2011.

19. Kornaś J. Oddziaływanie człowieka na florę: mechanizmy i konsekwencje. Wiad Bot. 1981; 25(3): 165-182.

20. Szymankiewicz K, Jankowska D, Deryło S. Wpływ płodozmianu i monokultury oraz sposobu uprawy roli na bioróżnorodność flory zachwaszczającej pszenżyto ozime [Effect of crop rotation, monoculture and soil tillage o biodiversity of flora infesting winter triticale]. Acta Agroph. 2003; 1(4): 767-772.

21. Jędruszczak M, Antoszek R. Sposoby uprawy roli a bioróżnorodność zbiorowisk chwastów w monokulturze pszenicy ozimej [Tillage systems and biodiversity of weed communities in winter wheat monoculture]. Acta Sci Pol Agric. 2004; 3(2): 47-59.

22. Woźniak A. Weed infestation of a spring wheat (Triticum aestivum L.) crop under the conditions of plough and ploughless tillage. Acta Agrobot. 2011; 64(3): 133-140. http://dx.doi.org/10.5586/aa.2011.040

23. Sowiński J. Zmiany stopnia zachwaszczenia kukurydzy w zależności od sposobu pielęgnacji [Changes of weed density in maize depending on weed control methods]. Prog Plant Prot Post Ochr Roślin. 2006; 46(2): 142-144.

24. Pudełko J, Skrzypczak G, Maciejewski T. Zachwaszczenie kukurydzy uprawianej po ziemniakach i zbożach [Weed populations resulting from forecrop in maize]. Prog Plant Prot Post Ochr Roślin. 2006; 46(2): 210-214. 
25. Gołębiowska H, Kaus A. Wpływ zróżnicowanych systemów uprawy na stan zachwaszczenia kukurydzy [Influence of diversified tillage systems on weed infestation in crop maize]. Prog Plant Prot Post Ochr Roślin. 2009; 49(2): 792-796.

26. Jezierska-Domaradzka A, Domaradzki K. Solidago canadensis L. jako potencjalny gatunek energetyczny - zagrożenia dla środowiska przyrodniczego oraz ocena naturalnych zasobów surowca na przykładzie wybranych odłogowanych pól w powiecie wołowskim na Dolnym Śląsku [Solidago canadensis L. as a potential energy plant - the risk to the environment and the estimation of natural raw material resources in the chosen fallow fields in Wołów County (Lower Silesia)]. Zesz Nauk Wroc. 2012; 584(C): 43-51.

\section{Udział antropofitów w następstwie roślin: pszenica ozima, kukurydza, pszenica jara w zależności od sposobu uprawy roli}

\section{Streszczenie}

$\mathrm{W}$ doświadczeniu przeprowadzonym w latach 2008-2010 oceniano wpływ systemu uprawy roli na występowanie oraz skład gatunkowy antropofitów w pszenicy ozimej, kukurydzy i pszenicy jarej. Niezależnie od rośliny uprawnej oraz zastosowanego systemu uprawy roli, główny składnik flory w badanych roślinach uprawnych stanowiły antropofity $(73,9 \%)$, reprezentowane przez archeofity i kenofity, natomiast pozostałe $26,1 \%$ przypadało na apofity. Najwięcej archeofitów stwierdzono w uprawie zerowej w łanie pszenicy jarej (13 gatunków), a najmniej w uprawie tradycyjnej w łanie pszenicy ozimej (6 gatunków). Jedyny stwierdzony kenofit - Conyza canadensis, występował tylko w uprawie zerowej w łanie pszenicy jarej oraz kukurydzy. W obrębie archeofitów gatunkami dominującymi były następujące taksony: Geranium pusillum, Anthemis arvensis i Viola arvensis (niezależnie od sposobu uprawy roli i rośliny uprawnej), Anthemis arvensis (w pszenicy jarej - uprawa tradycyjna), Echinochloa crus-galli i Setaria glauca (w kukurydzy - uprawa uproszczona i zerowa), Chenopodium album (w kukurydzy - uprawa zerowa) oraz Apera spica-venti, Anthemis arvensis i Papaver rhoeas (w pszenicy ozimej - uprawa zerowa).

Handling Editor: Bogusław Sawicki

This is an Open Access digital version of the article distributed under the terms of the Creative Commons Attribution 3.0 License (creativecommons.org/licenses/by/3.0/), which permits redistribution, commercial and non-commercial, provided that the article is properly cited. 